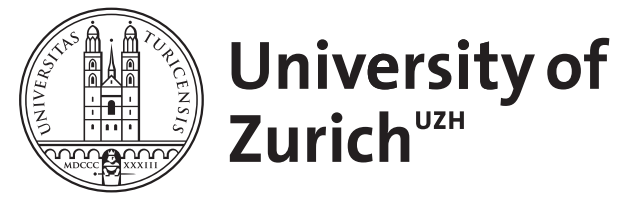

\title{
Law and Wisdom according to Deut 4:5-8
}

\author{
Krüger, Thomas
}

Posted at the Zurich Open Repository and Archive, University of Zurich ZORA URL: https://doi.org/10.5167/uzh-84386

Book Section

Published Version

Originally published at:

Krüger, Thomas (2013). Law and Wisdom according to Deut 4:5-8. In: Schipper, Bernd U; Teeter, D Andrew. Wisdom and Torah: The Reception of 'Torah' in the Wisdom Literature of the Second Temple Period. Leiden, Boston: Brill, 35-54. 


\title{
LAW AND WISDOM ACCORDING TO DEUT 4:5-8
}

\author{
Thomas Krüger*
}

Deuteronomy 4:5-8 is an important text for the question of the relationship of Wisdom and Torah in the Hebrew Bible. Only here are Wisdom and Torah related to each other in the Pentateuch. ${ }^{1}$ How this is done is not immediately clear and our contribution wants to shed light on the understanding of this difficult text.

\section{The Context of Deut 4:5-8}

Deuteronomy 4:5-8 is part of a long speech of Moses running from Deut 1:6-4:40. This speech falls into two parts: Deut 1:6-3:29 and 4:1-40. ${ }^{2}$ There is some evidence that Deut 4:1-40 is of a later provenance than its current context. $^{3}$ In view of its literary and thematic complexity, it is frequently assumed that the passage originated in several phases. ${ }^{4}$ Timo Veijola has characterized the structure and contents of Deut 4:1-40 as follows:

The admonitions to keep the commandments of Yahweh form the outer framework, which are the necessary condition for entering the land and a successful life within it (v. 1 and 40). Within this framework, the following themes come to expression: the inviolability of the commandments of Yahweh, which permit neither additions nor deletions (v. 2), the Baal-peor episode as a cautionary example of the fate of apostates (vv. 3-4), the distinctive wisdom and justice of the law given to Israel in the eyes of the nations (vv. $5^{-8}$ ), an urgent call to keep the first commandment, on which the life and death of the people depend (vv. 9-31), and finally the non-repeatable nature of Israel's experience of God and the singularity of his God (vv. 32-39).5

* English translation Anselm C. Hagedorn (Berlin). German manuscript completed May 1, 2012.

1 Thomas Krüger, "Gesetz und Weisheit im Pentateuch," in Auf den Spuren der schriftgelehrten Weisen (ed. Irmtraud Fischer et al.; BZAW 331; Berlin and New York: Walter de Gruyter, 2003), 1-12.

2 Karin Finsterbusch, Deuteronomium. Eine Einführung (UTB 3626; Göttingen: Vandenhoeck \& Ruprecht, 2012), 49.

3 On the discussion see Finsterbusch, Deuteronomium, 66-67.

4 Ibid.

5 "Den äußeren Rahmen bilden Mahnungen zum Einhalten der Gebote Jahwes, was die Bedingung für das Hineinkommen ins Land und das gelungene Leben in ihm sind 
Deuteronomy 4:1-4 motivates the admonitions to keep the "statutes and commandments" taught by Moses by pointing to the past experiences of the people of Israel (v. 3: "your eyes have seen..."). These experiences demonstrate that those members of the people who defied the first commandment by following Baal-Peor were wiped out by Yahweh, whereas those who held fast to Yahweh are still alive. Therefore, if one wants to stay alive, one is well advised to do what Yahweh demands, whatever that may be.

Deuteronomy 4:gff, referring again to Israel's past experiences (v. 9: "... what your eyes have seen"), argues in a similar vein but in a slightly more complex and differentiated way. At Mt. Horeb and on the basis of the ten words, Yahweh made a covenant with Israel that forbids the manufacture of idols. Because they did not see any form of Yahweh at Mt. Horeb, be it because Yahweh hid his form or because he is invisible, it is impossible for the Israelites to create an image of Yahweh. Since the Israelites experienced Yahweh as a "consuming fire" and a "jealous God" (4:24) at Mt. Horeb, they have to expect that they, just like their ancestors, will be destroyed by this God if they do not obey him.

\section{The Argumentation of Deut $4: 5^{-8}$}

Unlike these two passages, the call to obedience to the law in Deut 4:5-8 is not motivated by a threat of God's might and his will to punish. Rather, the verses point (i) to the positive consequences of obedience to the law for the international reputation of Israel (v. 6), (ii) to the closeness of God (v. 7), and (iii) to the quality of the law (v. 8).

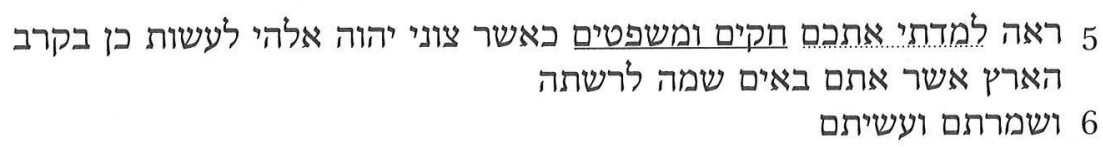

(V. 1 und 40). Innerhalb dieses Rahmens kommen die folgenden Themen zur Sprache: die Unantastbarkeit der Gebote Jahwes, die weder Ergänzungen noch Abstriche erlauben (V. 2), die Baal-Pegor-Episode als warnendes Beispiel für das Schicksal der Abtrünnigen (V. 3-4), die einzigartige Weisheit und Gerechtigkeit des Israel gegebenen Gesetzes in den Augen der Völker (V. $5^{-8}$ ), ein eindringlicher Aufruf zum Halten des ersten Gebotes, von dem Leben und Tod des Volkes abhängen (V. 9-31), und schließlich die Einmaligkeit der Gotteserfahrung Israels und die Einzigkeit seines Gottes (V. 32-39)." Timo Veijola, Das füfte Buch Mose / Deuteronomium: Kapitel 1,1-16,17 (ATD 8/1; Göttingen: Vandenhoeck \& Ruprecht, 2004), 96-97. 
כי הוא חכמתכם ובינתכבם לַעיניני העצמיסים אשר ישמעון את כל החקים האלה

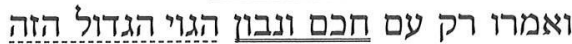

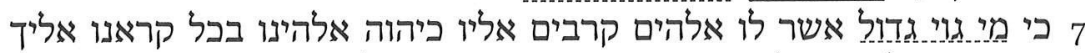

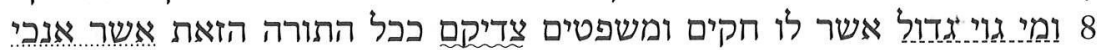

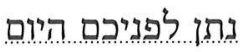

(5) See, ${ }^{6}$ I have taught you laws and rules, as Yahweh my God has commanded me to do so in the land that you are about to enter and take possession of it.

(6) Observe (them) and do (so)!

For that will be your wisdom and your discernment in the eyes of the people who will hear all these laws and say: "Surely this great nation is a wise and discerning people."

(7) For what great nation is there that has gods who are so close as is Yahweh our God whenever we call upon him?

(8) And what great nation has laws and rules as just as this entire Torah that I set before you this day?

\section{a. Verse 5}

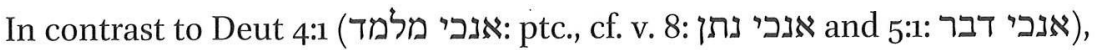
by using למדתי v. 5 seems to refer to a teaching of the law that has already occurred in the past. ${ }^{7}$ In the current context this can only refer to the laws

6 Since Moses addresses the Israelites in vv. $5^{-8}$ (plural), the imperative plural of as in the Samaritan Pentateuch fits the following better than the singular of MT. ראה, however, may be understood as an interjection (like הנה) that is not conjugated; see HAL, $\mathrm{Ges}^{18}$.

7 The perfect למדתי is often understood as expressing a performative action in the present (cf. Moshe Weinfeld, Deuteronomy 1-11 [AB 5; New York: Doubleday, 1991], 193: "I am teaching you"; Lothar Perlitt, Deuteronomium [BK V/4; Neukirchen-Vluyn: Neukirchener Verlag, 2006], 280: "ich lehre euch"). However, in contrast to Deut 1:8 (ראה נתתי לפניכם את הארץ), we do not have a coincidence of utterance and action here. The translation "Herewith I teach you..." (cf. Georg Braulik, "Deuteronomium 1-4 als Sprechakt," Bib 83 (2002): 249-57, esp. 250-51) is logically incorrect. With the statement נתתי לפניכם את הארי האי למדתי אתכם למת למני חקים ומשפטים the utterance is completed; cf. Andreas Wagner, Sprechakte und Sprechaktanalyse im Alten Testament (BZAW 253; Berlin and New York: Walter de Gruyter, 1997), 126. If the perfect is interpreted as a futurum exactum ("I will have taught"; Karin Finsterbusch, Weisung für Israel. Studien zu religiösem Lehren und Lernen im Deuteronomium und in seinem Umfeld [FAT 44; Tübingen: Mohr Siebeck, 2005], 149-50) the question remains why, e.g., Deut 4:1 
and rules mentioned in Exodus-Numbers. ${ }^{8}$ If that is the case, it is difficult to understand how v. 8 can say that Moses only now sets "this entire Torah" (that is apparently identical with the "laws and rules" mentioned in v. 8 and v. 5) before the Israelites. Are we expected to imagine that Moses now submits to the Israelites the "laws and rules" that he taught them as "this entire Torah" so that they can now take a stand on them, or that he again presents to the Israelites all the "laws and rules" which he had already taught them and summarizes these laws as "this entire Torah"? Or do we have an inconsistency here that the authors or redactors of the text simply overlooked? ${ }^{9}$

In any case, "this entire Torah" (Hebr. תורה) is a teaching that Moses delivered at the behest of Yahweh. This is stated by כאשר צוני יהוה אלהי, a statement that interrupts the train of thought (the following phrase לעשות כן... למדתי אתכם חקים ומשפטים connects to).

\section{b. Verse 6}

In verse 6 Moses asks the Israelites at first to keep the "laws and rules" that they have learned from him (and that are not mentioned in the text, but are tacitly to be inferred) and to act accordingly (ושמרתם ועשיתם). The remaining verse contains a first explanation of this admonition: the Israelites will be a wise and discerning people in the eyes of the nations because of their (observance of the) law.

It is not clear to what the pronoun הוא as in the Samaritan Pentateuch) refers. Does it (i) refer to the keeping and following of the laws as Moses requested from the Israelites (ששמרתם ועשיתם); does it (ii) refer to the "laws and rules" that Moses taught to

is not formulated in a similar way, since here, too, we are dealing with instructions for the behavior of Israel after the teaching by Moses.

8 חקים and משפטים, however, only occur in Lev 26:46. According to Finsterbusch (Deuteronomium, 59, n. 29), this verse was formulated by the "pentateuchal redaction" in view of the terms for laws used in Deuteronomy (with reference to Christophe Nihan, From Priestly Torah to Pentateuch [FAT II/25; Tübingen: Mohr Siebeck, 2007], 551-52). The combination of תורת משפטים (plural!), however, is difficult to reconcile with the deuteronomic concept of תורה (singular!).

9 Carl Steuernagel (Das Deuteronomium [HKI/3/1; Göttingen:Vandenhoeck \& Ruprecht, $\left.{ }^{2} 1923\right] 65$ ) assumed that in an earlier edition of Deuteronomy, Deut 4:5-8* (without v. 7 and the conclusion of v. 8 ) once stood after the laws (Deut $12-26^{*}$; cf. ibid., 9). See also August Dillmann, Die Bücher Numeri, Deuteronomium und Josua (KeH 13; Leipzig: S. Hirzel, 21886), 230, 253 .

10 For such an interpretation see, e.g., Veijola, Das füfte Buch Mose, 111, who understands the texts as Moses' praise of Israel's adherence to the law as wisdom and, as such, the reason for the recognition of Israel by the nations. 
the Israelites (and to which the text now refers to by using the singular הוא instead of the plural המא in v. 8); cf. כל התורה הזאת or or does it (iii) refer to the facts and circumstances described in v. 6 b (from (ישמעון that then has to be understood as a conditional clause: "if they will hear..., they will say"? ${ }^{12}$

(i) Syntactically, the first mentioned understanding of the text seems to be the most natural: When the Israelites follow the law, this will be their wisdom and discernment in the eyes of the nations - that is to say, the Israelites will be regarded by the nations as wise and discerning. ${ }^{13}$ However, the following sentence does not state that the observance of the law by the Israelites is the reason why the nations call them a wise and discerning people, but rather the notice of the law by the nations ("they will hear these laws and say..."). This prompts the question whether the Israelites are seen as wise in the eyes of the nations because they obey the law taught by Moses or because they have this law? Since the text wants to motivate the Israelites to follow the law, it is probably not interested in separating the one from the other: the Israelites will be regarded as wise and discerning if and because their laws are good and if and because they obey these laws. It is equally possible to understand v. 6 in such a way that the nations will be interested in the laws because of Israel's exceptional law-observance. If that is the case, the opinion of the nations regarding Israel rests not only upon its formal obedience to the law, but also upon the material quality of the laws the Israelites follow.

11 See, e.g., Eduard Nielsen, Deuteronomium (HAT I/6; Tübingen: Mohr, 1995), 56-57: "Der Zusammenhang spricht eher dafür, dass die Weisheit des Volkes einfach darin besteht, dass es die gerechten Satzungen und Rechtsbestimmungen, wie diese ganze Tora' besitzt, von Gott geschenkt, durch Mose vermittelt. Die Bundesordnung ist Israels Weisheit."

12 This seems to be the interpretation of the Vulgate: haec est enim vestra sapientia et intellectus coram populis ut audientes universa praecepta haec dicant en populus sapiens et intellegens gens magna. The Septuagint, too, understands v. $6 \mathrm{~b}$ as a conditional clause but

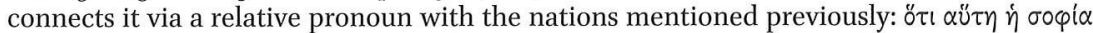

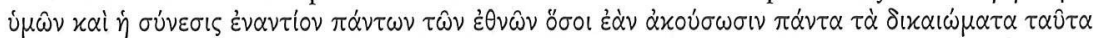

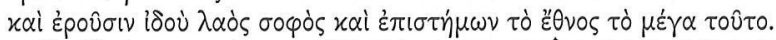

13 Cf. the paraphrase of Rashi: בזאת תחשבו חכמים ונבונים לעיני העמים "through this you will be considered wise and understanding in the eyes of the peoples."-Compare also the Zürcher Bibel: "darin zeigt sich den Völkern eure Weisheit und eure Einsicht"; NRSV: "this will show your wisdom and discernment to the peoples"; NJPS Tanakh: "that will be proof of your wisdom and discernment to other peoples"-According to Christof Hardmeier (Erzähldiskurs und Redepragmatik im Alten Testament [FAT 46; Tübingen: Mohr Siebeck, 2005], 165-66), לעשות כi v. 5 does not only mean that the Israelites shall observe the laws taught by Moses but also that they, like Moses, should teach them. In this light, Hardmeier argues that היא//הוא does not simply refer to observance but also to the teaching of the law by the Israelites. 
(ii) The second understanding of the text is easier semantically than the first one. Because of their laws the Israelites are regarded as wise and discerning in the eyes of the nations. Syntactically, however, one has to assume an incongruity of number between היא or and the הוא and ה. 14 Moreover, the nations do not praise the law (as Moses does a little later in v. 8) but Israel. Do they assume that Israel is the author of the law? Or are they of the opinion that the Israelites became especially wise and discerning by these good laws? Pragmatically, there exists a certain tension between the demand to follow the law and the justification of such a demand by the note that Israel will be regarded as wise and discerning amongst the nations because of its law (and not because it follows the laws). This tension vanishes if one tacitly assumes that it would be foolish not to follow such impressive laws. Accordingly, such an appraisal implies that Israel, as a wise and discerning people, indeed follows the laws. What Deut 4:6 states explicitly according to the first understanding (i), the verse would logically imply according to the second understanding (ii): the Israelites are seen as a wise and discerning people because they have good laws and because they follow them.

(iii) The same has to be said of the third possibility of understanding the verse: If the wisdom and discernment of the Israelites - according to the nations-consists in being regarded as wise and discerning in the eyes of the nations when they get to know Israel's laws, it is impossible to think that the Israelites did not follow their own laws. Rather, this implies that they do follow them. As a result, this third understanding (iii) implies what the first interpretation (i) states explicitly. However, we then have to assume a rather ponderous manner of expression.

Materially there are no fundamental differences between the three possibilities of understanding Deut 4:6. In any case, Deut 4:6 certainly assumes that the Israelites addressed deem it worthwhile to be regarded as wise and discerning by the nations. To reach this goal they should, in any case, keep and follow the law. Since the nations praise Israel as a wise and discerning people, this implies in turn that they do not regard the law as bad. One has to note, however, that the nations do not label the law, but Israel, as wise and discerning (the adjective חכבם is only used in reference to living beings or gods in the Hebrew Bible).

14 See most recently, e.g., Bernd U. Schipper, Hermeneutik der Tora (BZAW 432; Berlin: Walter de Gruyter, 2012), 94: "In 4,5f werden diese 'Satzungen und Rechtsbestimmungen' JHWHs (חקים ומשפטים) als Israels הכמה und בינה bezeichnet." 
From the perspective of the nations, the relationship of Israel's law and wisdom is described according to Deut 4:6 as follows: Israel's wisdom is that it has and keeps the law taught to it by Moses. The text never says that this view of the nations is wrong. In the following, however, the text adds two further points in v. 7 and v. 8 from the perspective of Moses leaving open whether the nations are of the same opinion.

\section{c. Verse 7}

Deut 4:7 differs from the context both in form and in content. Only here does Moses, by using "we," incorporate himself into the Israelites. Also, the topic of the verse is no longer the law and its observance but the closeness of God that is indicated by the fact that God listens to the prayers of the Israelites. ${ }^{15}$ Is the verse a late addition that shifts the thematic focus of the text away from the law and its observance to the superiority of Israel

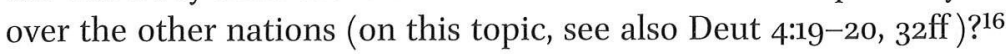

It is possible that v. 7 is mindful of the fact that the Torah originated, at least in parts, in specific judgments that Yahweh gave at Israel's request. ${ }^{17}$ Here Moses fulfils a similar role as during the proclamation of the laws (Exodus 19ff; Deuteronomy 4ff): he is the intermediary between Yahweh and the Israelites. Since Deut 30:11ff stresses that the Mosaic law is very close to the mouth and the heart of the Israelites, this implies that that the mediatorial office of Moses lapses after his death because the written law now enables each Israelite to ascertain at any time what Yahweh expects from the members of his people and how one has to regulate conflict. ${ }^{18}$ In this sense, God is close to the Israelites as lawgiver and judge (Deut 4:7) in the Torah.

15 Cf. 1 Kgs 8:52; Ps 34:18-19; 145:18-19 and the rendering of the verse in Targum Onqelos: "For who is such a great nation whose God is so close to it to accept its prayer in time of its tribulation like the Lord our God whenever we pray before Him?" English translation according to Bernard Grossfeld, ed., The Targum Onqelos to Deuteronomy. An English Translation of the Text with Analysis and Commentary (ArBib 9; Edinburgh: T \& T Clark, 1988), 28.

16 Thus, e.g., Steuernagel, Das Deuteronomium, 65; Veijola, Das fünfte Buch Mose, 110-11.

17 See Exod 18:13ff; Num 15:32ff; 36:1ff and also 1 Sam 12:32 (Samuel prays for the Israelites and teaches them the good and straight way).

18 For such an interpretation of Deut 30:11ff, see esp. Ernst Ehrenreich, Wähle das Leben! Deuteronomium 30 als hermeneutischer Schlüssel zur Tora (BZAR 14; Wiesbaden: Harrassowitz, 2011), 211ff-the significance of the prophets announced in Deut 18:9ff as successors to Moses is thus heavily qualified. 


\section{d. Verse 8}

Verse 8 refers to the "laws and rules" (v. חקים ומשפטים 5 הכקים) or "all these laws" (v. 6 (כל החקים האלה) as "this entire Torah" (כלמים התורה הזאת) and predicates them as "more just" (צדיקם, Sam. צדיקים) than the laws of the other nations. The statement is exceptional in that the adjective צדיק in the Hebrew Bible is generally used only with reference to living beings and gods. ${ }^{19}$ In contrast to Deut $4: 6$, where the evaluation of the wisdom and discernment of Israel is made by the nations, in verse 8 Moses proclaims that the mosaic law is more "just" than all other laws, and he solicits approval of such a view by the Israelites. ${ }^{20}$ Can we conclude then that Moses does not expect that the nations will realize that the "laws and rules" taught by him are just? Since he thinks them capable of recognizing the "wisdom and discernment" of the law-abiding Israelites (v. 6), such a conclusion appears unlikely. Maybe Moses is simply not sure that the nations will realize and accept that the Mosaic law is more just than their own laws. Perhaps, however, he simply wants the Israelites to keep the Torah not only out of the hope for respect from the nations (v. 6) but also because of their own insight (v. 8). In any case, the note about the "justice/ righteousness" of the laws as a motive for their observance points beyond a motivation by reward and punishment. It is not the fear of punishment or the hope for a reward but the sense of justice and striving after it that shall motivate the Israelites to keep the laws.

\section{Deuteronomy 4:5-8 within the ConteXt of the Hebrew Bible}

\section{a. Moses as Teacher of the Law (Deut 4:5)}

Deuteronomy 4:5 is one of the few passages within the Pentateuch where the law is the object of teaching and learning. ${ }^{21}$ The distribution of the

19 See Bo Johnson, "צדק," TDOT 12:239-63, 257. Psalm 19:10 describes laws as "just" by

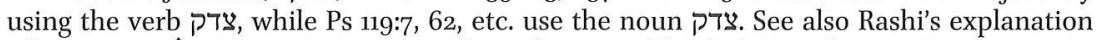
of הגונים ומקובלים as i.e. "worthy and reasonable" (Selig Bamberger, Raschis Pentateuchkommentar [Basel: Victor Goldschmidt, $\left.{ }^{4} 1994\right]$ ).

20 If v. 7 is a later addition (see above), v. 8 (minus the last sentence אשר אנכי נתן (לפניכם היום could have been the original continuation of the statement of the nations in v. 6; or, if one regards the introductory כי כ of 7 as original instead of the 9 in v. 8, the justification of this statement; cf. Steuernagel, Das Deuteronomium, 65 .

למד pi.: Deut 4:1, 5, 14; 5:31; 6:1 (subject: Moses); Deut 11:19 (subject: Israelites); למד q.: Deut 5:1; 31:12 (subject: Israelites and foreigners). Cf. "to teach/to learn to fear Yahweh" in Deut 4:10; 14:23; 17:19; 31:12-13 and "to teach the song (of Moses)" in Deut 31:19, 22. See also 
evidence suggests that the development from lawgiving to teaching of law is to be associated with the expansion of the deuteronomic law from an instrument of regulating conflict and structuring society (חקים ומשפטים) to a teaching of life (תורה, Lebenslehre) that is valid for, and that has to be learned by, every Israelite (and foreigner). This development is reflected in the various headings of Deuteronomy (Deut 12:1; 6:1; 4:44-45 [cf. 5:1; 4:1]). As a result, the expression חקים ומשפטים is now used also for the teaching in Deut $1-11$ (or at least Deut $4-11$ ). ${ }^{22}$ If that is the case, the use of the term "to teach" indicates the transformation of the (deuteronomic) law into a sapiential teaching of life. ${ }^{23}$ This kind of reinterpretation of the תורה can be seen also, for instance, in Psalm 119.

\section{b. The Assessment of the Law by the Nations and its Observance by the Israelites (Deut 4:6)}

Deuteronomy 4:6 presupposes that the Israelites strive for recognition by other nations. This striving is not criticised. This view of the nations differs sharply from other passages in Deuteronomy: Israel is required to massacre or expel the nations that occupy the Promised Land and to destroy their cultural heritage (Deut 12; 20). At best, individual members of the other nations can join the Israelite cultic community (Deut 24:2ff).

Among the later texts in the frame of Deuteronomy, there are, however, also texts stating that Yahweh is concerned about the wellbeing of the nations (cf.Deut 2:2off; 32:8; 33:3). Several passages talk about the perception of Israel and its history on the part of the nations. According to Deut 2:25, for example, the nations will tremble and quake when they hear of Israel's success during the conquest of the land. If the Israelites will keep the law, they will be blessed by Yahweh; then the people of the earth will see that

Exod 24:12 (ירה hi., object: מצוה תורה and subject: Yahweh or Moses); Lev 10:11 (ירה hi.,

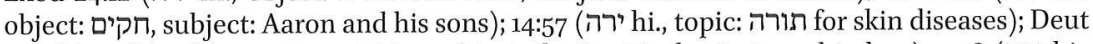
17:10f (ירה hi., object: תורת or, subject: the Levitical priests and judges); 24:8 (ירה hi., subject: the Levitical priests, topic: instructions regarding the treatment of skin diseases); 33:10 (ירה hi., object: משפטים/תורה משים and subject: the Levites).

22 On the problem of חקים ומשפטים and their reference in Deuteronomy, see Finsterbusch, Weisung, 229ff. Finsterbusch's view that the expression always refers to Deut $12 \mathrm{ff}$ is difficult to maintain for Deut 4:44-45 and 6:1. Do not the Decalogue and the Shema belong to the חקים ומשפטים? For a different view see, e.g., Weinfeld, Deuteronomy, 234-35.

23 Regarding the development "from law to ethics" in the Biblical legal corpora see Eckart Otto, Theologische Ethik des Alten Testaments (ThW 3/2; Stuttgart et al.: Kohlhammer, 1994), 18ff. On Otto's interpretation of Moses as a teacher of law in Deut 4 (Eckart Otto, Das Deuteronomium im Pentateuch und Hexateuch [FAT 30; Tübingen: Mohr Siebeck, 2000], 164-5) see Finsterbusch, Deuteronomium, 59-6o. 
Yahweh's name is proclaimed over Israel and they will stand in fear of Israel (Deut 28:10). In contrast, the nations will mock Israel when it, as punishment for its disobedience, is dispersed among the people (Deut 28:37). According to Deut $32: 43$, the nations shall praise Yahweh when he has avenged the blood of his servants and wrought vengeance on his adversaries.

To keep Yahweh from annihilating Israel in the wilderness, Moses argues that the Egyptians would misunderstand such a deed (Deut 9:28). According to Deut 32:27ff, Yahweh again shrinks back from the destruction of Israel because he fears that such a destruction will be misinterpreted by Israel's enemies who will attribute it to their own power rather than to Yahweh's might. While the passages mentioned assume a misjudgment of the nations, Deut 29:23ff thinks them capable of a correct assessment - at least when they were taught by an informed Israelite (or foreigner?):

... all nations will ask: Why did Yahweh do this to this land? Wherefore this severe, burning wrath? They will be told: Because they forsook the covenant of Yahweh, the god of their ancestors... and they went and worshipped other gods and prostrated themselves before them...therefore Yahweh's wrath was inflamed against this land so that he brought upon it all the curses recorded in this book. In anger, fury, and severe wrath Yahweh uprooted them from their soil and cast them into another land, where they still are today.

A comparison of this passage with Deut 4:6 is interesting, because Deut 29:23-25 implies that the nations acquire at least some rudimentary knowledge of the Torah ("this book"), at least of the curses contained therein and their function. Deuteronomy 4:6 then presupposes an even broader knowledge of the Torah on the part of the nations. Outside Deuteronomy the thought that the nations become acquainted with the Torah is only mentioned in Isa 2:2ff (// Mic 4:1ff) and 54:4 (cf. 42:1). By contrast, the Hebrew Bible often reports Israel's or Judah's perspective on the laws and customs of the other nations. ${ }^{24}$ Leviticus 18:3 states that Israel shall not live according to the חקת of the Canaanites but must follow the חקת of Yahweh. Ezekiel 11:12 accuses the Israelites that they did not live according to the משפטים משים and Yahweh but oriented themselves toward the משפטים of the surrounding nations. According to Ezek 5:6-7 the Israelites forsook Yahweh's משפטים and acted

24 See, e.g., Judg 18:7; 2 Kgs 17:33 (משפט)); Lev 18:30; 20:23; 2 Kgs 17:8 (דרקת); Jer 10:2); Lev 18:3 (מעשה); Ps 106:35 (מעשים). 
more wickedly than the nations around them, while not even keeping the משפטים of the nations which thus are still better than evil (רשעה) and chaos (המון). When it is announced that the nations will judge Jerusalem according to their משפטים (Ezek 23:24), it is obvious that the nations in general are not seen as lawless and immoral. If one compares and evaluates in such a way one's own laws and customs with the laws and customs of others, it is likely that one will at some point continue this train of thought - as is donę in Deut 4:6 - and contemplate how one is perceived and assessed by the nations.

\section{c. Law and Wisdom (Deut 4:6)}

The conviction expressed in Deut 4:6 that the possession and observance of the Torah will earn the Israelites the reputation of a wise and discerning people in the eyes of the nations is without parallel in the Hebrew Bible. Proverbs 28:7 states that it is wise to observe the Torah (נוצר תורה בן מבין, "He who observes the Torah is an intelligent son"; see also 28:4, 9; 29:18). Here, however, תורה does not refer to the Mosaic law but-as is generally the case in the Book of Proverbs - to the teaching of the parents or the sages. ${ }^{25}$ If the observance of this teaching lets a person "find favour and approbation in the eyes of God and people" as stated in Prov 3:Iff, one can argue that a statement about the Mosaic law in Deuteronomy (Deut 4:6) is transferred here to the sapiential teaching of Proverbs, as is the case elsewhere in Proverbs 1-9. Thus, it is indicated that this teaching may be equal, or even be superior, to the Mosaic law. ${ }^{26}$ The opposite of such tradition-oriented wisdom in Proverbs 3 is to trust in one's own understanding (v. 5), an imaginary wisdom (v. 7 "wise in your own eyes") that is alleged not to have faith in Yahweh and not to fear him. A current of a tradition-critical wisdom may be in view here, as can be detected in Job and Qoheleth. Proverbs 1-9 distances itself explicitly from such wisdom, while a life oriented exclusively by the Torah is only criticized implicitly.

In contrast to Deut 4:6, Proverbs does not reflect upon the behavior of the Israelites as a collective entity. ${ }^{27}$ Rather, the book addresses issues of

25 See Otto Plöger, Sprüche Salomos (BKAT XVII; Neukirchen-Vluyn: Neukirchener Verlag, ${ }^{2}$ 2003), 333-4, 347 .

26 See Schipper, Hermeneutik, 235: "Durch diesen Bezug [i.e., the statements of Deuteronomy about the quality of the Mosaic law] rücken die Tora und Gebote des Weisheitslehrers bzw. von Vater und Mutter in die Nähe der Gebote JHWHs."

27 See Schipper, Hermeneutik, 10off, $287 \mathrm{ff}$; Bernd U. Schipper, "Das Proverbienbuch und die Toratradition," ZTK 108 (2011): 381-404. 
how the life of individual persons is lived in harmony with the order of the cosmos (Proverbs 8). The same can be said of Psalm 19 and Psalm 119. ${ }^{28}$ Here, the Torah mediates wisdom — or perhaps better, the Torah mediates the same virtues as wisdom does elsewhere. ${ }^{29}$ The texts suggest that this happens exclusively by the Torah and that wisdom in this sense is defined by the Torah, ${ }^{30}$ because they do not mention another source of wisdom besides the Torah. (Or is the observation of the heavens in Psalm 19 an additional source of wisdom?). On the other hand, the texts do not state explicitly that only the Torah mediates wisdom. Additionally, the relationship of the תורה mentioned here to the Pentateuch is not quite clear. ${ }^{31}$

This latter observation is equally true for Sir 24:23 where wisdom is identified with the "Book of the covenant of the most high God" ( $\beta$ i $\beta$ ios

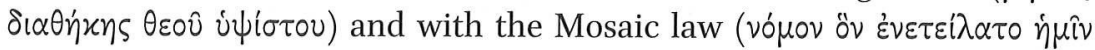

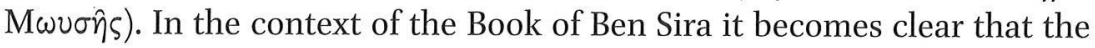
Law may be an excellent source of wisdom, ${ }^{32}$ but hardly its only source (cf. Sirach 39). ${ }^{33}$ Also the law does not make all of Israel wise, but only the scribal elite (cf. Sir 38:24ff).

While Sirach 24 integrates the Mosaic law within a more comprehensive wisdom; Bar 3:9-4:4, in turn, reduces wisdom to the Mosaic law. ${ }^{34}$ Under this condition a statement such as Deut 4:6 would have been impossible since the nations neither know the Mosaic law nor do they have the necessary wisdom to evaluate it. Deuteronomy 4:6 presupposes

28 See Schipper, Hermeneutik, uff; Alexandra Grund, Die Himmel erzählen die Herrlichkeit Gottes (WMANT 103; Neukirchen-Vluyn: Neukirchener Verlag, 2004); Kent A. Reynolds, Torah as Teacher. The Exemplary Torah Student in Psalm 119 (VTSup 137; Leiden and Boston, Mass.: Brill, 2010).

29 See Reynolds, Torah, 131ff: "Psalm 119 borrows the praises of wisdom in order to praise the benefits of Torah, but in doing so the author of Psalm 119 avoids using words for wisdom" (ibid. 131).

30 Thus Schipper, Hermeneutik, 124 on Ps 19.

31 See Reynolds, Torah, $126 \mathrm{ff}$.

32 See Johannes Marböck, Weisheit im Wandel (BZAW 272; Berlin and New York: Walter de Gruyter, ${ }^{2}$ 1999), 94: "für Israel ist die Weisheit... am sichersten und besten greifbar in der Torah; vor den Völkern der Welt ist die Torah Israels Weisheit".

33 Cf. Odil H. Steck, Das apokryphe Baruchbuch (FRLANT 16o; Göttingen: Vandenhoeck \& Ruprecht, 1993), 156: In Sirach 24 the law is included in a more comprehensive wisdom ("das Gesetz in die weiterreichende Weisheit einbezogen"). Cf. Marböck's point that Ben Sira is silent about typical Jewish laws such as circumcision and Sabbath (Weisheit, 93).

34 Cf. Steck, Baruchbuch, 156: "Nichts anderes als das allein Israel gegebene Gesetz ist diese Weisheit; hier ist ihr einzig zugänglicher Ort" (see ibid. 116ff). 
that the nations and Israel possess the wisdom necessary to understand and apply the law correctly. This is apparently not a problem. ${ }^{35}$

Finally Psalm 147 is of interest for a comparison with Deut 4:6. The Psalm praises the power and wisdom of God (v. 5) that manifests itself in the fact that "he proclaimed his commandments to Jacob, his statutes and rules (משפטים חקים) to Israel" (v. 19). While in Deut 4:6 the wisdom of the Israelites manifests itself in the observance of the law, in Psalm 147 the law itself is an indication of the wisdom of Yahweh, the lawgiver. According to Ps 147:20, the disclosure of the law privileges Israel over other nations: "He did not do so for any (other) nation; they do not know his rules." The text does not suggest that this will change at some point. Thus it is closer to Baruch 3-4 than to Deut 4:6.

\section{d. The Closeness of God (Deut 4:7)}

If it is true, as argued above, that God in Deut 4:7 is close to the Israelites in the guise of the Mosaic law, this fits well with the presentation of the theophany at Mt. Horeb described in 4:9ff. ${ }^{36}$ It stresses that the Israelites perceived no shape of Yahweh (v. 12, 15). They heard his voice (v. 12), but whether they understood what Yahweh said to them is not quite clear. ${ }^{37}$ As a result the appearance of Yahweh on Mt. Horeb leads to the giving of the ten words written down by Yahweh himself to Israel (v. 13) and to the commissioning of Moses to impart to them laws and rules (v. 14). After this is done in Deuteronomy, God is present for Israel in the form of both texts, the Decalogue and the Torah.

This concept of the closeness of God in the text of the Torah and in the Decalogue is opposed to the concept, widespread in the Hebrew Bible, of

35 On the necessity of wisdom for an interpretation of the law, see Deut 1:9ff; 16:19; 34:9. Deuteronomy 29:3/30:6 express doubts about whether the Israelites have such wisdom and offers possibilities to acquire such wisdom. The prophetic statements about the change or renewal of the human heart by God (Jer 31 ; Ezek 36 etc.) address the same problem. According to Wisdom 9 God has to give wisdom to human beings so that they can understand the commandments of God. Extreme positions are formulated in Num 5:37ff (the Israelites should observe the commandments of God and should not follow their own heart and eyes, i.e., their own deliberations and experiences) and Qoh 11:9 (God will condemn the human person if he does not follow his heart and his eyes).

36 See Thomas Krüger, "Zur Interpretation der Sinai/Horeb-Theophanie in Dtn 4,10-14," in Schriftauslegung in der Schrift (ed. Reinhard G. Kratz et al.; BZAW 300; Berlin and New York: Walter de Gruyter, 2000), 85-94.

37 See Martin Rose, 5. Mose/Deuteronomium (vol. 2; ZBK.AT 5; Zürich: Theologischer Verlag Zürich, 1994), 495; Thomas Krüger, "Die Stimme Gottes," in Gottes Wahrnehmungen (ed. Stefan Gehrig et al.; Stuttgart: Kohlhammer, 2009), 41-64, see $59 \mathrm{ff}$. 
the closeness of God in the sanctuary or in Jerusalem or on Mt. Zion, ${ }^{38}$ a concept critically examined in the prophetic tradition. ${ }^{39}$

\section{e. The Righteousness of the Law (Deut 4:8)}

Though the Pentateuch largely seems to presuppose that the provisions of the Mosaic law are just, only Deut 4:8 states this explicitly. Deuteronomy 6:25 and 24:13 come closest here as both verses say that the Israelites will be

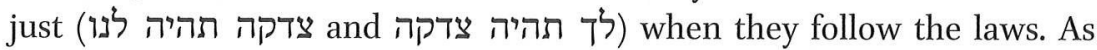
Deut 16:20 urges Israel to pursue justice (צדק צדק תרדף) after the demand of just jurisdiction (18:18-19; cf. Lev 19:15; Deut 1:16), this may be understood as transcending the narrow context of legal affairs, and thus pointing to a more general principle of life.

These passages, like Deut 4:8, presuppose that it is more or less evident what is to be regarded as just. It is not the Torah that determines what is just and righteous, but rather the Torah is judged and evaluated by the scale of justice. By contrast, texts like Psalm 19 and especially Psalm 119 that, like Deut 4:8, speak explicitly of the righteousness of the laws and rules of Yahweh ${ }^{40}$ — as well as the Book of Wisdom — seem to define righteousness and justice on the basis of Torah

\section{Extrabiblical Horizons}

It is a part of the common sense of ancient Near Eastern cultures-or better, of the ruling ideology prevalent in these cultures - that the royal jurisdiction, as well as its codification in legal collections, displays the wisdom and righteousness/justice of the ruler. The tale of the Solomonic judgment in 1 Kings 3 illustrates this worldview, as do the narrative frames of the Mesopotamian legal collections. ${ }^{41}$ Deuteronomy $4: 6,8$ takes up this tradition but no longer speaks of the wisdom and righteousness of the lawgiver. Rather the verses stress the wisdom of the people who follow their laws, as well as the righteousness of the laws.

38 See, e.g., Exod 25ff; 1 Kgs 8; 2 Chr 6; Ezek 4off; Ps 46; 48; 65:5; 73:28; 84:11.

39 See esp. Jer 7.

40 See Ps 19:10; Ps 119:7, 62, 75, 106, 123, 138, 144, 160, 164, 172.

41 See Georg Braulik, Studien zur Theologie des Deuteronomiums (SBAB 2; Stuttgart: Katholisches Bibelwerk, 1988), 69ff, 84ff; Georg Braulik, Studien zum Buch Deuteronomium (SBAB 24; Stuttgart: Katholisches Bibelwerk, 1997), 254ff; Gerhard Ries, Prolog und Epilog in Gesetzen des Altertums (MBPF 76; München: Beck, 1983); Martha T. Roth, Law Collections from Mesopotamia and Asia Minor (SBLWAW 6; Atlanta, Ga.: Scholars Press, ${ }^{2} 1997$ ). 
This transformation of traditional concepts became necessary since Deuteronomy 4 no longer wants to legitimate a ruler before his people by his legislation. Rather, Deuteronomy 4 focuses on the justification of the laws of one people (Israel) before other nations (and their rulers). Such a situation arose for the Israelites or Judeans during Achaemenid rule. Even though there might not have existed a proper institution of an "imperial authorization" of local laws and customs, we have, nevertheless, enough evidence that the Achaemenid rulers were interested in the customs and laws of their subjects. Perhaps in some cases they even espoused the preservation of and compliance with such laws and customs. ${ }^{42}$

A Demotic text, for example, reports that Darius (I) instructed the Satrap of Egypt to send to him "the sages" of Egypt so that they could "write down the previous law of Egypt", the "law of Pharaoh, the temple, (and) the people." This was done. The laws were recorded on a papyrus scroll and a copy was made using "Assur script and epistolary script," i.e., Aramaic and Demotic. ${ }^{43}$ This may have been more a collection of customs and the knowledge of Egypt in general as known to us from the walls of the Hibis-Temple in the oasis of El Khargeh than a codification of Egyptian law. ${ }^{44}$

In the Hebrew Bible the Artaxerxes rescript preserved in Ezra 7:11ff. attests - despite its questionable historicity ${ }^{45}$ - the notion that the Persian king takes care that the "law of your [i.e., Ezra's] God and the law of the king" are observed in the province of Yehud (7:26). Additionally the king can speak of the law of Ezra's God as "divine wisdom" (7:25). ${ }^{46}$

42 Cf. Peter Frei and Klaus Koch, Reichsidee und Reichsorganisation im Perserreich (OBO 55; Fribourg and Göttingen: Universitätsverlag and Vandenhoeck \& Ruprecht, ${ }^{2}$ 1996); Josef Wiesehöfer, Das frühe Persien (C. H. Beck Wissen 2107; München: C. H. Beck, 1999), 6gff; Konrad Schmid, "Persische Reichsautorisation und Tora," ThR 71 (2006): 494-506; Amélie Kuhrt, The Persian Empire (vol. 2; London and New York: Routledge, 2007), 849ff; David Carr, An Introduction to the Old Testament (West Sussex: Wiley-Blackwell, 2010), 207ff; Erich Zenger et al., Einleitung in das Alte Testament (ed. Christian Frevel; KStTh 1/1; Stuttgart: Kohlhammer, ${ }^{8}$ 2012), $152 \mathrm{ff}$.

43 Wilhelm Spiegelberg, Die sogenannte demotische Chronik des Pap. 215 der Bibliothèque Nationale zu Paris nebst den auf der Rückseite des Papyrus stehenden Texten (Leipzig: J. C. Hinrichs'sche Buchhandlung, 1914), 30-1; vgl. Diodorus Siculus I, 94-5: Kuhrt, Persian, 849-50.

44 Anke Joisten-Pruschke, Das religiöse Leben der Juden von Elephantine in der Achämenidenzeit (GOF.I III/2; Wiesbaden: Harrassowitz, 2008), 78-9, vgl. $77 \mathrm{ff}$.

45 See Sebastian Grätz, Das Edikt des Artaxerxes. Eine Untersuchung zum religionspolitischen und historischen Umfeld von Esra 7,12-26. (BZAW 337; Berlin and New York: Walter de Gruyter, 2004); Sebastian Grätz, "Gottesgesetz und Königsgesetz," ZTK 106 (2009): 1-19.

46 Cf. Antonius H. J. Gunneweg, Esra (KAT XIX/1; Gütersloh: Gütersloher Verlagshaus, 1985), 137: "Die ,Weisheit in Esras Hand" ist dasselbe, was V 14 als ,Gesetz in deiner Hand" 
In their inscriptions, the Achaemenid rulers not only praise their own uprightness, ${ }^{47}$ but they also designate themselves as lawgivers according to the will of Ahuramazda and call for the observance of the law of Ahuramazda:

Saith Darius the King: Much, which was ill-done, that I made good. Provinces were in commotion, one man smiting the other. The following I brought about by the favor of Ahuramazda, that the one does not smite the other at all, each one is in his place. My law - of that they feel fear, so that the stronger does not smite nor destroy the weak. ${ }^{48}$

$\mathrm{O}$ man, that which is the command of Ahuramazda, let this not seem repugnant to thee; do not leave the right path; do not rise in rebellion. ${ }^{49}$

Thou who (shalt be) hereafter, if you should think "Happy may I be when living and when dead may I be blessed," have respect for that law which Ahuramazda has established; worship Ahuramazda and Arta reverent(ly). The man who has respect for that law which Ahuramazda has established, and worships Ahuramazda and Arta reverent(ly), he both becomes happy while living, and becomes blessed when dead. ${ }^{50}$

In the light of the self-representation of the Achaemenid kings, it is certainly possible to conceive the idea that one could be praised by such rulers for the observance of the laws of one's own god (Deut 4:6).

During the $5^{\text {th }}$ century BCE Herodotus, too, shows a strong interest in the customs, practices and laws of different peoples. ${ }^{51}$ He does not only describe them, but often also evaluates them. ${ }^{52}$ In Hist. I 8 Gyges explains why it is sensible and useful to study the customs and practices of other

bezeichnet worden war... daß diese... Gleichung auf der... Vorstellung beruht, daß das Gesetz Inbegriff der Weisheit und die wahre Weisheit im Gesetz enthalten sei, wie sie Bar 4,1; Sir 24,23.25 begegnet, ist hingegen nicht so sicher."

47 See DB $\$ 63$ (Rüdiger Schmitt, Die altpersischen Inschriften der Achaimeniden. Editio minor mit deutscher Übersetzung [Wiesbaden: Reichert, 2009], 83); DNb §2ff (Schmitt, Inschriften, 106ff ); XPl §2ff (Schmitt, Inschriften, 171ff).

48 DSe $\S_{4}$ (English translation acc. to Roland G. Kent, Old Persian: Grammar, Text, Lexicon [American Oriental Series 33; New Haven: American Oriental Society, ${ }^{2} 1953$ ], 142), an inscription of Darius I. from Susa about the restoration of order in the empire, fragmentarily preserved on different material (Schmitt, Inschriften, 14). Vgl. Schmitt, Inschriften, 101-2 (DNa §3), 124 (DSe §3), 165-6 (XPh §3).

49 DNa $\S 6$ (Kent, Old Persian, 138), an inscription from the upper register of the façade of the tomb of Darius I. at Naqsh-i Rustam (Schmitt, Inschriften, 11).

$50 \mathrm{XPh} \S 4 \mathrm{~d}$ (Kent, Old Persian, 152), the so-called "Daiva" inscription of Xerxes I. from Persepolis (Schmitt, Inschriften, 20).

51 See, e.g., Hist. I 131ff (Persians); I 195ff (Babylonians); II 35ff, 77ff (Egyptians); IV $59 f f$ (Skyths) etc. All translations from Herodotus are taken from A.D. Godley, Herodotus in Four Volumes (Loeb Classical Library 117-120; Cambridge, Mass.: Harvard University Press, repr. ed. 1990).

52 See, e.g., Hist. I 137: "This is a law which I praise..."; I 197: "I come now to the next wises of their customs ..."; I 199: "The foulest custom is ..."; II 35 "... the Egyptians ... have 
people: "Men have long ago made wise rules for our learning." In Hist. II 160 Herodotus reports that messengers from Elis ask Egyptian sages for advice about how to make the most just rules of competition for the Olympic games. Hist. II 104 illustrates how laws and customs of one nation can influence others. According to Herodotus, one has to respect the differences in laws and customs among the various people. Since Cambyses did not do this, Herodotus declares him "very mad":

... else he would never have set himself to deride religion and custom. For if it were proposed to all nations to choose which seemed best of all customs, each, after examination, would place its own first; so well is each convinced that its own are by far the best. It is not therefore to be supposed that anyone, except a madman, would turn such things to ridicule. (Hist. III 38 ).

In principle, loyalty to one's own customs and laws is thus laudable. ${ }^{53}$ The cliché of the Jews as a nation of philosophers in Hellenistic times demonstrates that the expectation voiced in Deut 4:6 that they will be regarded as a wise and discerning people because of the obedience to the Mosaic law is not completely illusory. ${ }^{54}$ According to an attractive conjecture proposed by Adrian Schenker, this expectation could have been one of the motives for a translation of the Torah into Greek. The translation would then be an attempt to make the law known to the nations. ${ }^{55}$

\section{Conclusion}

If the reflections presented above are correct, Deut 4:5-8 is not a discussion of the relationship between Wisdom and Torah in principle. Rather, the verses express the desire that Israel's obedience to the Mosaic Law will

made all their customs and laws of a kind contrary for the most part of those of all other men"; II 177: "a perfect law" etc.

53 See, e.g., Hist. IV 80: "This is how closely the Scythians guard their customs, and these are the penalties they inflict on those who add foreign customs to their own"; IV 106: "The Man-eaters are the most savage of all men in their way of life; they know no justice and obey no law"; VI 106: The Spartans "were unwilling to break the law"; VII 102: in Hellas "courage is acquired as the fruit of wisdom and strong law".

54 See Martin Hengel, Judentum und Hellenismus. Studien zu ihrer Begegnung unter besonderer Berücksichtigung Palästinas bis zur Mitte des 2. Jh.s v. Chr. (WUNT 10; Tübingen: Mohr Siebeck, ${ }^{3}$ 1988); Arnaldo Momigliano, Hochkulturen im Hellenismus (München: C. H. Beck, 1979); Peter Schäfer, Judeophobia. Attitudes Toward the Jews in the Ancient World (Cambridge, Mass.: Harvard University Press, 1997).

55 Adrian Schenker, "Was führte zur Übersetzung der Tora ins Griechische?" in Die Septuaginta-Texte, Theologien, Einflüsse. 2. Internationale Fachtagung veranstaltet von Septuaginta Deutsch (LXX.D), Wuppertal 23.-27. Juli 2008 (ed. Wolfgang Kraus and Martin Karrer; WUNT 252; Tübingen: Mohr Siebeck, 2010), 23-34. 
lead to its recognition by the nations. Moses is, to be sure, of the opinion that the laws taught by him are superior to the legislation of the nations (4:8). He expects nothing more of the nations, however, than that they regard the observance of those laws by the Israelites as reasonable, as a mark of wisdom and insight (4:6), and that, on this basis, they tolerate the laws, if not promote them.

Such an expectation fits well in the Persian period. Here at least an influential intellectual group in the province Yehud cherished the hope that the Mosaic Law (whatever its concrete form) would be accepted by the Achaemenid rulers as a local order of life. That this hope was fulfilled is reported (in a historically questionable way) in Ezra 7:1ff. Later on, the religious politics of Antiochus IV directed against such local laws, according to 1 Maccabees 1 , led to the Maccabean revolt.

Even though Deut $4: 5^{-8}$ is not a statement about the relationship between Wisdom and Torah in principle, the text probably initiated deeper and more exact reflection about this relationship-especially since, owing not least to the increasing knowledge of the laws and customs of other peoples, the question would, over the course of time, unavoidably arise as to whether all Mosaic laws are indeed as just and reasonable as Deut 4:5-8 claims.

\section{BIBLIOGRAPHY}

Bamberger, Selig. Raschis Pentateuchkommentar. Basel: Victor Goldschmidt, ${ }^{4} 1994$.

Botterwerk, Johannes G., Helmer Ringgren, and Heinz-Josef Fabry: Theological Dictionary of the Old Testament. Translated by Douglas W. Stott. 15 vols. Grand Rapids, Mich., and Cambridge, U.K.: Eerdmans, 1975-2012.

Braulik, Georg. Studien zur Theologie des Deuteronomiums. Stuttgarter biblische Aufsatzbände 2. Stuttgart: Katholisches Bibelwerk, 1988.

—. Studien zum Buch Deuteronomium. Stuttgarter biblische Aufsatzbände 24. Stuttgart: Katholisches Bibelwerk, 1997.

- "Deuteronomium 1-4 als Sprechakt." Biblica 83 (2002): 249-57.

Carr, David. An Introduction to the Old Testament. West Sussex: Wiley-Blackwell, 2010.

Dillmann, August. Die Bücher Numeri, Deuteronomium und Josua. Kurzgefasstes exegetisches Handbuch zum Alten Testament 13. Leipzig: S. Hirzel, ${ }^{2} 1886$.

Ehrenreich, Ernst. Wähle das Leben! Deuteronomium 30 als hermeneutischer Schlüssel zur Tora. Beihefte zur Zeitschrift für altorientalische und biblische Rechtgeschichte 14 . Wiesbaden: Harrassowitz, 2011.

Finsterbusch, Karin. Weisung für Israel. Studien zu religiösem Lehren und Lernen im Deuteronomium und in seinem Umfeld. Forschungen zum Alten Testament 44. Tübingen: Mohr Siebeck, 2005.

- Deuteronomium. Eine Einführung. Uni-Taschenbücher 3626. Göttingen: Vandenhoeck \& Ruprecht, 2012.

Frei, Peter, and Klaus Koch. Reichsidee und Reichsorganisation im Perserreich. Orbis biblicus et orientalis 55. Fribourg and Göttingen: Universitätsverlag and Vandenhoeck \& Ruprecht, 1996. 
Godley, A. D. Herodotus in Four Volumes. Loeb Classical Library 117-120. Cambridge, Mass.: Harvard University Press, repr. ed. 1990.

Grätz, Sebastian. "Gottesgesetz und Königsgesetz." Zeitschrift für Theologie und Kirche 106 (2009): 1-19.

- Das Edikt des Artaxerxes. Eine Untersuchung zum religionspolitischen und historischen Umfeld von Esra 7,12-26. Beihefte zur Zeitschrift für die alttestamentliche Wissenschaft 337. Berlin and New York: Walter de Gruyter, 2004.

Grossfeld, Bernard. The Targum Onqelos to Deuteronomy. An English Translation of the Text with Analysis and Commentary. The Aramaic Bible 9. Edinburgh: T \& T Clark, 1988.

Grund, Alexandra. Die Himmel erzählen die Herrlichkeit Gottes. Wissenschaftliche Monographien zum Alten uņd Neuen Testament 103. Neukirchen-Vluyn: Neukirchener Verlag, 2004.

Gunneweg, Antonius H. J. Esra. Kommentar zum Alten Testament XIX/1. Gütersloh: Gütersloher Verlagshaus, 1985 .

Hardmeier, Christof. Erzähldiskurs und Redepragmatik im Alten Testament. Forschungen zum Alten Testament 46. Tübingen: Mohr Siebeck, 2005.

Hengel, Martin. Judentum und Hellenismus. Studien zu ihrer Begegnung unter besonderer Berücksichtigung Palästinas bis zur Mitte des 2. Jh.s v. Chr. Wissenschaftliche Untersuchungen zum Neuen Testament 10. Tübingen: Mohr Siebeck, ${ }^{3} 1988$.

Herodot. Historien. Edited by Hans-Wilhelm Haussig. Translated by August Horneffer. Stuttgart: Kröner, 1971.

Joisten-Pruschke, Anke. Das religiöse Leben der Juden von Elephantine in der Achämenidenzeit. Göttinger Orientforschungen Reihe 3: Iranica Neue Folge 2. Wiesbaden: Harrassowitz, 2008.

Kent, Roland G. Old Persian: Grammar, Text, Lexicon. American Oriental Series 33. New Haven, Conn.: American Oriental Society, ${ }^{2} 1953$.

Krüger, Thomas. "Zur Interpretation der Sinai / Horeb-Theophanie in Dtn 4,10-14." Pages 85-94 in Schriftauslegung in der Schrift. Edited by Reinhard Gregor Kratz, Thomas Krüger, and Konrad Schmid. Beihefte zur Zeitschrift für die alttestamentliche Wissenschaft 30o. Berlin and New York: Walter de Gruyter, 2000.

—. "Gesetz und Weisheit im Pentateuch." Pages 1-12 in Auf den Spuren der schriftgelehrten Weisen. Edited by Irmtraud Fischer, Ursula Rapp, and Johannes Schiller. Beihefte zur Zeitschrift für die alttestamentliche Wissenschaft 331. Berlin and New York: Walter de Gruyter, 2003.

- . "Die Stimme Gottes." Pages 41-64 in Gottes Wahrnehmungen. Edited by Stefan Gehrig and Stefan Seiler. Stuttgart: Kohlhammer, 2009.

Kuhrt, Amélie. The Persian Empire. Vol. 2. London and New York: Routledge, 2007.

Marböck, Johannes. Weisheit im Wandel. Beihefte zur Zeitschrift für die alttestamentliche Wissenschaft 272. Berlin and New York: Walter de Gruyter, ${ }^{2} 1999$.

Momigliano, Arnaldo. Hochkulturen im Hellenismus. München: C. H. Beck, 1979.

Nielsen, Eduard. Deuteronomium. Handbuch zum Alten Testament I/6. Tübingen: Mohr Siebeck, 1995 .

Nihan, Christophe. From Priestly Torah to Pentateuch. Forschungen zum Alten Testament II/25. Tübingen: Mohr Siebeck, 2007.

Otto, Eckart. Das Deuteronomium im Pentateuch und Hexateuch. Forschungen zum Alten Testament 30. Tübingen: Mohr Siebeck, 2000.

—. Theologische Ethik des Alten Testaments. Theologische Wissenschaft $3 / 2$. Stuttgart et al.: Kohlhammer, 1994.

Perlitt, Lothar. Deuteronomium. Biblischer Kommentar Alten Testament V/4. NeukirchenVluyn: Neukirchener Verlag, 2006.

Plöger, Otto. Sprüche Salomos. Biblischer Kommentar zum Alten Testament XVII. Neukirchen-Vluyn: Neukirchener Verlag, ${ }^{2} 2003$.

Preuss, Horst Dietrich. Deuteronomium. Erträge der Forschung 164. Darmstadt: Wissenschaftliche Buchgesellschaft, 1982. 
Reynolds, Kent A. Torah as Teacher. The Exemplary Torah Student in Psalm 119. Supplements to Vetus Testamentum 137. Leiden and Boston, Mass.: Brill, 2010.

Ries, Gerhard. Prolog und Epilog in Gesetzen des Altertums. Münchener Beiträge zur Papyrusforschung und antiken Rechtsgeschichte 76. München: Beck, 1983.

Rose, Martin. 5. Mose / Deuteronomium. Vol. 2. Züricher Bibelkommentare zum Alten Testament 5. Zürich: Theologischer Verlag Zürich, 1994.

Roth, Martha T. Law Collections from Mesopotamia and Asia Minor. SBL Writings from the Ancient World Series 6. Atlanta, Ga.: Scholars Press, ${ }^{2} 1997$.

Schäfer, Peter. Judeophobia. Attitudes Toward the Jews in the Ancient World. Cambridge, Mass.: Harvard University Press, 1997.

Schenker, Adrian. "Was führte zur Übersetzung der Tora ins Griechische?" Pages 23-34 in Die Septuaginta-Texte, Theologien, Einflüsse. 2. Internationale Fachtagung veranstaltet von Septuaginta Deutsch (LXX.D), Wuppertal 23.-27. Juli 20o8. Edited by Wolfgang Kraus and Martin Karrer. Wissenschaftliche Untersuchungen zum Neuen Testament $25^{2}$. Tübingen: Mohr Siebeck, 2010.

Schipper, Bernd U. "Das Proverbienbuch und die Toratradition." Zeitschrift für Theologie und Kirche 108 (2011): 381-404.

- Hermeneutik der Tora. Beihefte zur Zeitschrift für die alttestamentliche Wissenschaft 432. Berlin and Boston, Mass.: Walter de Gruyter, 2012.

Schmid, Konrad. "Persische Reichsautorisation und Tora." Theologische Rundschau 71 (2006): 494-506.

Schmitt, Rüdiger, Die altpersischen Inschriften der Achaimeniden. Editio minor mit deutscher Übersetzung. Wiesbaden: Reichert, 2009.

Spiegelberg, Wilhelm. Die sogenannte demotische Chronik des Pap. 215 der Bibliothèque Nationale zu Paris nebst den auf der Rückseite des Papyrus stehenden Texten. Leipzig: J. C. Hinrichs'sche Buchhandlung, 1914.

Steck, Odil Hannes. Das apokryphe Baruchbuch. Forschungen zur Religion und Literatur des Alten und Neuen Testaments 16o. Göttingen: Vandenhoeck \& Ruprecht, 1993.

Steuernagel, Carl. Das Deuteronomium. Handkommentar zum Alten Testament I/3/1. Göttingen: Vandenhoeck \& Ruprecht, ${ }^{2} 1923$.

Veijola, Timo, Das füfte Buch Mose / Deuteronomium: Kapitel 1,1-16,17. Das Alte Testament Deutsch 8/1. Göttingen: Vandenhoeck \& Ruprecht, 2004.

Wagner, Andreas, Sprechakte und Sprechaktanalyse im Alten Testament. Beihefte zur Zeitschrift für die alttestamentliche Wissenschaft, 253. Berlin and New York: Walter de Gruyter, 1997.

Weinfeld, Moshe. Deuteronomy 1-11. The Anchor Yale Bible Commentaries 5. New York: Doubleday, 1991.

Wiesehöfer, Josef. Das frühe Persien. C. H. Beck Wissen 2107. München: C. H. Beck, 1999.

Zenger, Erich et al. Einleitung in das Alte Testament. Edited by Christian Frevel. Studienbücher Theologie 1/1. Stuttgart: Kohlhammer, ${ }^{8} 2012$. 


\title{
Supplements
}

\author{
to the
}

\section{Journal for the Study of Judaism}

Editor

Benjamin G. Wright, III

Department of Religion Studies, Lehigh University

Associate Editors

Hindy Najman

Department of Religious Studies, Yale University

Eibert J.C. Tigchelaar

Faculty of Theology and Religious Studies, KU Leuven

Advisory Board

A.M. BERLIN - K. BERTHELOT - R. BLOCH - G. BOHAK J.J. COLLINS - J. DUHAIME - K. HOGAN - P.W. VAN DER HORST -

O. IRSHAI - A.K. PETERSEN - S. MASON - J.H. NEWMAN -

M.R. NIEHOFF - M. POPOVIĆ - I. ROSEN-ZVI -

J.T.A.G.M. VAN RUITEN - M. SEGAL - J. SIEVERS -

G. STEMBERGER - L.T. STUCKENBRUCK - J.C. DE VOS

VOLUME 163 


\section{Wisdom and Torah}

The Reception of 'Torah' in the Wisdom Literature of the Second Temple Period

Edited by

Bernd U. Schipper and D. Andrew Teeter

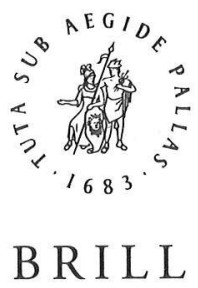

